\title{
Użycie form adresatywnych $w$ tekstach literackich jako odzwierciedlenie otwartości na doświadczenia
}

\author{
Dmytro Teterya \\ Uniwersytet Warszawski \\ dimtet@rambler.ru
}

\begin{abstract}
Streszczenie
W artykule podjęta została próba zastosowania koncepcji dystansów interpersonalnych wyrażanych $w$ tekstach literackich poprzez formy adresatywne do pomiaru stopnia otwartości na doświadczenia. Punkt wyjścia dla proponowanych rozważań stanowi teoria dystansów personalnych, dystansu psychofizycznego oraz koncepcja Carla Rogersa. Zdaniem Rogersa, otwartość na doświadczenie jest kluczem do sukcesu, gdyż organizm człowieka-pod wplywem przyswajanych nowych doświadczeń - jest w stanie szybko i elastycznie się zmieniać. W efekcie osoby o wysokim stopniu otwartości na doświadczenia wybieraja sytuacje $i$ zdarzenia pozytywnie wpływajace na ich ogólny rozwój. Analiza zostata przeprowadzona na podstawie a podstawie dwóch dramatów wspótczesnych: Requiem dla gospodyni autorstwa Wiesława Myśliwskiego $i$ Czwarta siostra autorstwa Janusza Głowackiego. Badanie miało na celu ustalenie, czy istnieje zależność pomiędzy dą̇eniem do zmniejszenia dystansu interpersonalnego między nadawca $i$ odbiorca komunikatu a stopniem otwartości na doświadczenia. Kolejnym zadaniem badawczym była ocena skuteczności autorskiego konstruktu badawczego $i$ odpowiedź na pytanie, czy prezentowana $w$ niniejszym artykule koncepcja dystansów interpersonalnych może być realnie wykorzystywana $w$ stosunku do jednostek ludzkich. Analizowane przykłady wypowiedzi bohaterów dwóch wybranych dramatów wskazuja na zależność między chęcia zmniejszania dystansu interpersonalnego a stopniem otwartości na doświadczenie.
\end{abstract}

Słowa kluczowe: dystans interpersonalny, teoria Carla Rogersa, formy adresatywne, otwartość na doświadczenia

The Use of Forms of Address in Literary Texts as a Reflection of Openness to Experience

\begin{abstract}
The article attempts to apply the concept of interpersonal distances expressed in literary texts through forms of address to measure the degree of openness to experience. The starting point for the proposed considerations is the theory of personal distances, psychophysical distance and the theory of Carl Rogers. According to Rogers, openness to experience is the key to success, because the human body is able to change quickly and flexibly under the influence of learned new experiences. As a result, people with a high degree of openness to experience choose situations and events that positively affect their overall development. The analysis was based on
\end{abstract}


two contemporary plays: Requiem for the hostess by Wiesław Myśliwski and The Fourth Sister by Janusz Gtowacki. The research aimed to determine whether there is a relationship between the desire to reduce the interpersonal distance between the sender and the recipient of the message and the degree of openness to experience. Another research task was to assess the effectiveness of the original research construct and to answer the question whether the theory of interpersonal distances presented in this article can be used in real terms in relation to individuals. The analyzed statements of the heroes of the two selected dramas indicate the correlation between the desire to reduce the interpersonal distance and the degree of openness to experience.

Key words: interpersonal distance, Carl Rogers' theory, forms of address, openness to experience

\section{Wstęp}

Zaczniemy od wyjaśnienia, czym dla Carla Rogersa jest pojęcie otwartości na doświadczenie. Do odpowiedniej i, naszym zdaniem, najbardziej trafnej interpretacji dostępnego materiału źródłowego, użyjemy metody dedukcji. Sedno sprawy leży w samorealizacji jednostki ludzkiej. Jak wiadomo, każdy organizm ludzki dysponuje określonymi możliwościami. Używamy tu określenia organizm ludzki, ponieważ Rogers ([1959]2016:33) uważał, że dążenie do samoaktualizacji odbywa się poprzez urzeczywistnianie się możliwości organizmu. W urzeczywistnieniu tychże możliwości pomaga dążenie do stałego, zdrowego i twórczego rozwoju. Tak jak w przypadku programu na komputerze, wymagającego co jakiś czas aktualizacji, w ten sam sposób organizm jednostki ludzkiej - rozwijając się - dokonuje procesu samoaktualizacji.

\section{Warunki otwartości na doświadczenia Carla Rogersa}

Proces samoaktualizacji, zdaniem Carla Rogersa ([1980]2012: 129), jest możliwy w określonych warunkach, takich jak bezwarunkowa akceptacja ze strony osób bliskich oraz akceptacja samego siebie. Wychowując się w warunkach pełnej akceptacji, jednostka ludzka potrafi określić, co się dzieje wokół jej organizmu, a jej świadomość jest w stanie to, co się dzieje, przyjąć i zaakceptować. Poprzez określanie i przyjmowanie bodźców zewnętrznych organizm ludzki wypracowuje doświadczenie, które w późniejszym etapie wspomaga sprawdzanie i wybieranie najlepszych, zdaniem organizmu, sytuacji oraz zdarzeń pozytywnie wpływających na ogólny rozwój człowieka. Innymi słowy, organizm dokonuje wyboru optymalnej formy samoaktualizacji ([1959]2016:71). 


\subsection{Otwartość na doświadczenia w warunkach pełnej akceptacji}

Organizm ludzki dorastający w warunkach pełnej akceptacji zostaje optymalnie przystosowany do zmieniających się warunków życia codziennego. Dzieje się tak dlatego, że organizm człowieka odbiera je w sposób naturalny i pozytywny. Pod tą naturalnością Rogers rozumie brak wypracowanych mechanizmów obronnych. Odpowiednio mechanizmy obronne interpretuje jako proces zniekształcania, pomijania lub wypierania ze świadomości ludzkiej bodźców przychodzących ze świata zewnętrznego lub wewnętrznego ([1961]2002: 229).

W efekcie jednostka ludzka sukcesywnie samorealizuje się w otaczającym ją świecie w oparciu o strukturę swojego organizmu. Człowiek, który dorastał w warunkach pełnej akceptacji, zazwyczaj jest osobą otwartą, tzn. pod wpływem nowego doświadczenia jest w stanie szybko i elastycznie się zmieniać. Ta otwartość na nowe doświadczenia, zdaniem Rogersa, jest kluczem do sukcesu ([1961]2002: 234).

\subsection{Otwartość na doświadczenia w warunkach częściowej akceptacji}

Zobaczmy teraz, co się dzieje w sytuacji niespełnienia wypracowanych przez Rogersa warunków. Mówimy zatem o braku we wczesnym dzieciństwie bezwarunkowej akceptacji i miłości ze strony rodziców. Przy tego typu relacjach, zdaniem Rogersa ([1980]2012: 234), niejako uczymy dziecko odbierać i przyswajać tylko te doświadczenia, które są zgodne z warunkami i wartościami narzucanymi przez rodziców. W konsekwencji doświadczenia, które W rzeczywistości mogą być dobre i korzystne dla samorealizacji jednostki ludzkiej, z powodu niezgodności z warunkami i wartościami rodziców, są przez organizm zniekształcane lub wypierane ze świadomości. Innymi słowy, tego typu napływające bodźce odbierane są jako zagrożenie. W odniesieniu do takich sytuacji Rogers mówi o pojęciu trafności odbierania wszelkich bodźców, która ma tendencję spadkową ze względu na brak zaufania do swojego organizmu ([1980]2012: 235). Osoba z niską trafnością odbierania bodźców staje się bardzo podatna na dominację własnych pojęć i wierzeń. Zdaniem Rogersa, jest to bardzo złe doświadczenie, ponieważ zostało ono przetestowane na rzeczywistości, lecz oparte na abstrakcji. Takie osoby klasyfikuje on jako osoby o niskim poziomie otwartości na doświadczenia ([1959]2016:89).

Dalej warto zastanowić się, czy uzyskanie przez jednostkę ludzką na określonym etapie życia niezbędnej akceptacji i miłości poprzez nawiązanie odpowiedniej relacji z bezwarunkowo akceptującą ją osobą przyczyni się do zmiany poziomu otwartości na doświadczenia. Czy taka osoba jest w stanie osiągnąć pełną otwartość na doświadczenia? Zdaniem Rogersa([1980]2012: 
236), jest to możliwe. Według autora koncepcji, na tym etapie mamy do czynienia z co najmniej trzema typami osób. Pierwszy typ to osoba bezwarunkowo akceptująca samą siebie i odbierane bodźce, ze stałym poziomem otwartości na doświadczenia. Drugim typem, według koncepcji Rogersa, jest osoba częściowo (warunkowo) akceptująca samą siebie i bodźce, o niskim poziomie otwartości na doświadczenie. Z kolei trzeci typ to osoba akceptująca samą siebie (w sposób zmienny warunkowo lub bezwarunkowo) o przejściowym poziomie otwartości na doświadczenia ([1959]2016:92).

Rozwijając myśl, Rogers próbuje połączyć otwartość na doświadczenia z pojęciem otwartości poznawczej ([1980]2012: 279). A więc, aby jednostka ludzka była w stanie skonstruować realny obraz siebie i świata, musi otworzyć się zarówno na bodźce pochodzące z własnego organizmu (otwartość na siebie), jaki ze świata zewnętrznego (otwartość na świat). Osoby o takim stopniu otwartości swobodnie wyrażają swoje emocje, pomysły, ufają swojemu organizmowi, żyją z poczuciem wewnętrznej harmonii, są w stanie realizować swoje potrzeby i poddawać ocenie nabyte doświadczenie. Proces ten wpływa także na aktualizację systemu wartości jednostki ludzkiej. Otwartość na doświadczenia może mieć nie tylko pozytywne, lecz też negatywne zabarwienie. Osoby otwarte na doświadczenia, przekonane o słuszności własnej oceny sytuacji, potrafią zachowywać się w sposób arogancki, są zarozumiałe, nie liczą się z opinią i uczuciami innych ludzi. Na przykład, osoby zatrzymane przez funkcjonariuszy policji dość często stosują wobec policjantów formy niegrzeczne. Niemniej jednak stosowanie form adresatywnych o zabarwieniu negatywnym jest dowodem otwartości na doświadczenie i może (chociaż nie musi) świadczyć o poziomie inteligencji nadawcy ([1980]2012: 251).

W swojej koncepcji Rogers zatrzymał się na etapie udowodnienia kluczowej roli pojęcia otwartości na doświadczenia dla prawidłowego procesu samorealizacji w szybko zmieniającym się społeczeństwie ([1961]2002: 242). Badacz nie skonstruował jednak narzędzia, które pozwoliłoby wnioskować o stopniu otwartości konkretnej osoby na doświadczenia i wpływie tegoż na wyżej wspomniany proces. W naszym przekonaniu, takim narzędziem może być koncepcja dystansów interpersonalnych wyrażanych przez formy adresatywne.

\subsection{Otwartość na doświadczenia a dystans interpersonalny}

W trakcie badań nad formami adresatywnymi zwróciliśmy uwagę, że do zmiany użycia przez nadawcę formy adresatywnej niezbędna jest akceptacja ze strony odbiorcy komunikatu. Ta akceptacja następuje w momencie skracania istniejącego dystansu interpersonalego. Warto w tym momencie zwrócić uwagę na różnicę pomiędzy pojęciem dystansu interpersonalnego a 
pojęciem dystansu personalnego. Ten ostatni jest przestrzenią między nadawcą i odbiorcą komunikatu, mierzoną w centymetrach. Dystanse personalne opisał Edward Hall ([1966] (1978: 163). Badacz interpretował odległość około $45 \mathrm{~cm}$ jako dystans intymny, do którego dopuszczane są jedynie osoby bardzo bliskie (mąż, żona, chłopak, dziewczyna, dziecko); odległość 45-120 cm jako dystans indywidualny (osobisty), in. strefę prywatną, do której dopuszcza się ludzi nam znanych (przyjaciele, dobrzy znajomi, rodzina); odległość 120 - 360 cm jako dystans społeczny, czyli dystans dla ludzi obcych i znajomych, z którymi nie wiążą nas zażyłe stosunki, w którym to dystansie załatwiane są także wszelkie sprawy oficjalne; odległość powyżej 4,5 m - jako dystans publiczny, t.j. odległość zachowywaną wobec osób publicznych ([1966]1978: 164). Tego typu podejście jest podejściem dosyć subiektywnym, ponieważ istnieją przypadki wpuszczania osób obcych do dystansu intymnego lub indywidualnego: nierzadkie są przecież rozmowy pomiędzy osobami obcymi stojącymi w zatłoczonym pociągu lub autobusie.

Odpowiednio dystans interpersonalny jest pojęciem szerszym, powiększonym o przestrzeń psychiczną. Dystans psychiczny rozumieć można jako postrzegane koszty uczenia się lub redukcji niepewności, związanej, według Ciszewskiej (2012: 15), z działaniem w warunkach różnic dotyczących języka, systemów edukacji, praktyk biznesowych, kultury oraz poziomu rozwoju przemysłu. Można zatem sądzić, że pojęcia dystansu interpersonalnego, dystansu personalnego i dystansu psychicznego są ze sobą powiązane: o ile dystans personalny oznacza odległość fizyczną zależną od stopnia bliskości psychiczno-emocjonalnej, o tyle dystans interpersonalny wydaje się wypadkową dystansu personalnego i psychicznego. Dobrym przykładem jest dystans interpersonalny osobisty, który częściowo łączy w sobie dwa dystanse personalne E. Halla, intymny i indywidualny (osobisty).

Przestrzeni psychicznej (jako składowej dystansu interpersonalnego) nie jesteśmy w stanie zmierzyć, natomiast jesteśmy w stanie w materiale źródłowym - tekstach literackich, znaleźć wydarzenia potwierdzające zmianę dystansu psychicznego (a w konsekwencji również dystansu interpersonalnego) wyrażaną poprzez użycie innej formy adresatywnej oraz brak negatywnych reakcji ze strony odbiorcy komunikatu. Pracując na materiale źródłowym, wykryliśmy ciekawą zależność, a mianowicie osoby o wysokim stopniu otwartości na doświadczenie (zakładamy, że są to osoby odnoszące sukcesy w swoich środowiskach społecznych) znacznie częściej podejmują próbę zmniejszania początkowego dystansu interpersonalnego, zawsze obecnego przy nadawaniu komunikatu. Osoby o niskim stopniu otwartości na doświadczenie (zakładamy, że są to osoby przeciętne, które nie mogą się poszczycić dużymi sukcesami w odpowiednich środowiskach społecznych) robią to znacznie rzadziej. Stąd też propozycja zastosowania (zaaplikowania) koncepcji dystansów 
interpersonalnych, wyrażanych poprzez formy adresatywne, jako narzędzia do pomiaru otwartości na doświadczenia.

Poniżej przedstawimy konstrukt, którym posłużymy się w celu weryfikacji zmniejszania stopnia dystansu interpersonalnego. Proponowany konstrukt badawczy pozwala wykryć w tekstach literackich ślady (dowody) potwierdzające obecność procesu przejścia od jednego dystansu interpersonalnego do drugiego. Dowodami są dla nas formy adresatywne. Użyta forma adresatywna dostarcza informacji na temat obecności procesu zmniejszania dystansu. Formy zwracania się klasyfikujemy pod względem czterech dystansów interpersonalnych, innymi słowy, dokonujemy segregacji koncepcyjnej. To oznacza, że w obrębie określonego dystansu interpersonalnego używamy odpowiedniej formy adresatywnej. Użycie tej formy świadczy o dystansie obecnym przy zwracaniu się do odbiorcy. Idąc tym tropem myślowym - im częściej jednostka ludzka używa form adresatywnych świadczących o dążeniu do zmniejszenia dystansu interpersonalnego w różnych okolicznościach życia codziennego, tym bardziej taka osoba jest otwarta na doświadczenia. Przypuszczamy, że stopień chęci zmniejszania dystansu świadczy o stopniu otwartości na doświadczenia według Carla Rogersa.

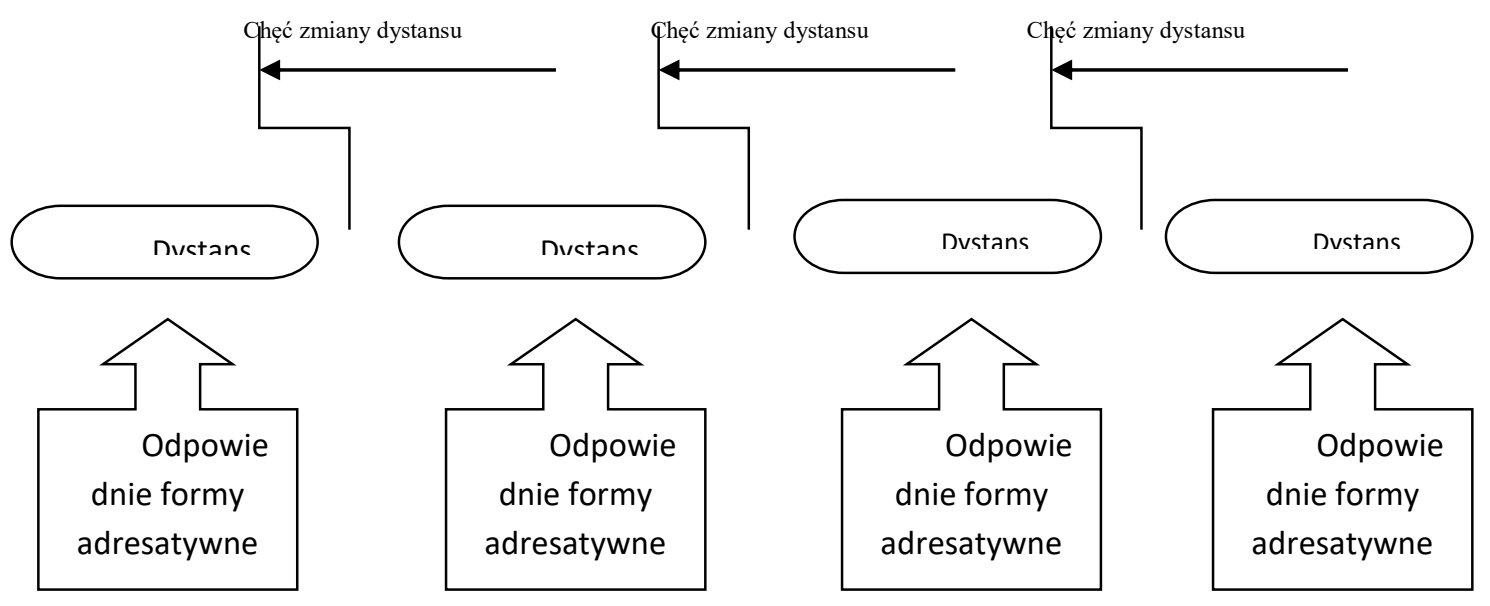

Ryc. 1. Konstrukt badawczy. Źródło: opracowanie własne.

\section{Analiza: pomiar otwartości na doświadczenia}

$\mathrm{Na}$ potrzeby niniejszego artykułu wprowadzamy trzy podstawowe stopnie otwartości na doświadczenia: niski, średni i wysoki. W tekstach literackich próby nawiązania kontaktu prowadzące do zmniejszenia dystansu jesteśmy w stanie zidentyfikować za pośrednictwem formy adresatywnej używanej względem odbiorcy komunikatu. Zwracamy uwagę, iż używanych względem odbiorcy komunikatu zaimków osobowych, zwłaszcza w formach 
przypadków zależnych(na przykład: ty, ci, cię), które nie są oddzielone przecinkami, nie interpretujemy jako form zwracania się, a jedynie jako formy sygnalizujące odpowiedni dystans osobisty. Poniżej podejmiemy próbę analizy stopnia otwartości na doświadczenie bohaterów dramatu Wiesława Myśliwskiego Requiem dla gospodyni, wydanej w roku 2012 oraz Janusza Głowackiego Czwarta siostra, wydanej w 1999 roku. Przeanalizujemy stopień otwartości na doświadczenia wybranych bohaterów dramatów, takich jak Gospodarz, Darek, Turysta, Turystka II, Emeryt, Businessman, a także Generał, Jurij Aleksiejewicz, Katia, Tania.

Na początek spróbujmy zidentyfikować rodzaj dystansu interpersonalnego obecnego między Gospodarzem a Weronką (młodszą córka, lat dwadzieścia kilka) oraz Bolesiem (pastuchem w wieku nieokreślonym, lecz raczej starym, szpetnym).

\section{PRZYKLAD: 1}

GOSPODARZ/WERONKA

WERONKA

Wie ojciec, gdzie mam ten wasz wstyd? Inne się nie wstydzą, to i łapią chłopów.

\section{GOSPODARZ}

Darek ci nie mówi, kiedy się będzie żenił?

\section{WERONKA}

Mówi, jak chce, żebym mu dała. Tak samo przedtem mówił Zenek, Zdzisiek, Romek. Gdzież ta cholerna bluzka? Bym dłużej ojca nie gorszyła.

\section{GOSPODARZ}

Nie mnie gorszysz. Pod jednym dachem wszyscyśmy, to nie da się nic zataić. Nawet co w środku, w sobie, człowiek nosi.

\section{WERONKA}

To co mi się ojciec każe wstydzić?

\section{GOSPODARZ}

Bo wstyd odróżnia człowieka od bydlęcia, córko.

(Mysliwski 2012: 632-633)

Względem córki ojciec zachowuje dystans osobisty. Świadczą o tym pronominalne formy ty, $c i$ oraz forma adresatywna córko. Trudno jest mówić o stopniu otwartości na doświadczenia $\mathrm{w}$ relacjach z bliskimi ludźmi. Osoby należące do jednej rodziny najczęściej zachowują względem siebie osobisty dystans interpersonalny. Chęć zmiany dystansu świadczyłaby o przejściu od dystansu osobistego do dystansu intymnego w stosunku do córki. W tym przypadku 
musielibyśmy mówić o niezdrowym zachowaniu się ojca. W wyżej opisanych warunkach odkrycie stopnia otwartości na doświadczenia badanego bohatera nie jest możliwe.

Porównajmy ten przykład z innym, również wskazującym na relacje pomiędzy ojcem i córkami.

\section{PRZYKLAD: 2}

GENERAŁ/TANIA/KATIA

GENERAŁ (rozgląda się za wódka)

Straszna grypa teraz w Moskwie, wszyscy chorują. Ale żeby szkołę zamykać?... Wiesz, Tanieczka, że ta twoja szkoła tańca zamknięta jest $\mathrm{z}$ powodu grypy. Przysłali zawiadomienie, gdzieś je miałem.

\section{TANIA}

Nie szkodzi, tatko.

\section{GENERAŁ (ciagle się rozglądając)}

Za tydzień mają otworzyć. A na razie ćwicz w domu. Rozmawiałem z twoim nauczycielem. Powiedział, że masz wielki talent. Wielki. Będzie z ciebie druga Plisiecka. Tak powiedział. Słowo honoru, cała szkoła jest z ciebie dumna. Tak mówił. A ty, Katieńka, też znajdziesz pracę odpowiednią. A Wiera znalazła (mówi trochę przez łzy) miłość. A to najważniejsze. Nie martwcie się, dzieci. Tylko ćwicz, Tanieczka, ćwicz. Wierzcie mi, dzieci. Ja wiem, co mówię.

\section{TANIA}

Tatko. Złóż też o wizę. Może nam dadzą, jedźmy wszyscy do Ameryki. Do wujaszka, on nam...

(Glowacki 1999: 404)

Generał, względem córek Tani i Kati, zachowuje dystans osobisty. Świadczą o tym, pronominalna forma ty, zdrobniałe formy adresatywne Tanieczka, Katieńka. Dystans ten potwierdzają odbiorcy komunikatu, córki Generała, używając familiarnej formy adresatywnej tatko. Zmniejszanie dystansu w tym przypadku nie jest możliwe z powodu, o którym pisaliśmy wcześniej, analizując dialog Ojca i Weronki. Brak możliwości zmniejszania dystansu skutkuje brakiem odkrycia otwartości na doświadczenia badanego bohatera.

Analizując używane formy adresatywne w ramach dystansu osobistego, wykryliśmy różne związki emocjonalne i psychiczne w relacjach ojców z córkami. Forma adresatywna tatko spotyka się $\mathrm{z}$ akceptacją $\mathrm{i}$ wdzięcznością ojca, wyrażaną formami zwracania 
się Tanieczka, Katieńka. Tak postrzeganej bliskości czy spoufalenia nie zauważyliśmy w relacjach Ojciec/Weronka.

Zanalizujmy teraz relacje pomiędzy osobami niespokrewnionymi.

\section{PRZYKLAD: 3}

GOSPODARZ/BOLEŚ

GOSPODARZ

Przyśniło ci się pewnie. Łąka, kiedy zmorzy, to z tamtego świata lubi się nawet przyśnić.

BOLEŚ

Nie zmrużyłem oka, to jak mogło mi się przyśnić? Nikogo jeszcze nie ma?

\section{GOSPODARZ}

Tych trzech. Jak do ciebie mówić?

\section{BOLEŚ}

Jeden, trzech, stu, śpiewania nie da się, gospodarz, policzyć. To jak w łąkę wsadzić głowę, a całą ziemię słychać.

(Mysliwski 2012: 631-632)

Wyżej przedstawiony fragment wskazuje na obecność między Gospodarzem i Bolesiem dwóch dystansów: osobistego i społecznego. Używane formy pronominalne ty, ci, ciebie świadczą o tym, że nadawca (Gospodarz) zachowuje względem odbiorcy (Bolesia) dystans osobisty, natomiast odbiorca (Boleś) względem nadawcy (Gospodarza) - dystans społeczny. Świadczy o tym forma nominalna, funkcyjna gospodarz. Chęci zmiany dystansu z jednej lub drugiej strony na tym etapie nie wykryto.

\section{PRZYKLAD: 4}

\section{TURYSTA/DAREK}

Wpada rozwścieczony Darek, na widok Turystów zatrzymuje się, wodząc rozbieganymi oczyma.

\section{DAREK}

Nie ma jej tu?

TURYSTA 
Pan kogoś szuka?

DAREK (dostrzegłszy urodziwe Turystki, rozaniela się)

Szukam. Ale mogę nie szukać.

TURYSTKA II (wdzięcząc się)

Jaki przystojny.

TURYSTA (widząc, że Darek zaczyna umizgiwać się do Turystki II)

Panie! Panie! Pana kto tu zaprosił?

(Myśliwski 2012: 681-682)

W tym miejscu mamy do czynienia $\mathrm{z}$ wydarzeniem doprowadzającym do natychmiastowego zmniejszenia dystansu między Darkiem a Turystką II oraz chęcią zmiany rodzaju dystansu. Chcąc nawiązać kontakt werbalny, Darek zbliża się do Turystki II. Zainteresowanie się osobą płci żeńskiej skutkuje chęcią użycia względem kobiety nominalnej formy adresatywnej ty i jak najszybszego zmniejszania początkowego dystansu. Początkowym dystansem, jak wynika z tekstu, jest dystans społeczny oraz fakt, iż Darek i Turystka II nie znali się wcześniej. Ze strony Turystki widzimy akceptację zamiaru zmniejszania dystansu społecznego, wyrażaną w tekście nie formą adresatywną, lecz odpowiedzią jaki przystojny. W tym momencie do rozmowy wtrąca się Turysta, używając formy Panie. Z jednej strony, Turysta potwierdza obecność dystansu społecznego między Darkiem a nadawcą komunikatu, z drugiej strony, przerywa trwający proces zmniejszania dystansu. Po krótkiej wymianie zdań Darek wybiega z izby, tym samym uniemożliwia czytelnikowi pozyskanie wystarczającej ilości dowodów na zmniejszanie dystansu. Niemniej jednak uważamy, że łatwość, z jaką Darek pokonuje dystans społeczny i przechodzi do dystansu osobistego, jest dla nas argumentem świadczącym o obecności średniego stopnia otwartości na doświadczenia.

\section{PRZYKLAD: 5}

GENERAŁ/BABUSZKA

\section{GENERAŁ}

Byłem u fryzjera. Wchodzę, on się pyta: „Co?”. Więc mówię: „Jak to co? Golenie”. To on, że do tego muszę podnieść głowę. To się kazałem ostrzyc. To ładnie, Akulino Iwanowna, żeś przyszła. Przyjaciół się poznaje.

\section{BABUSZKA}

Przecież ty dla mnie jesteś jak rodzony. Dwadzieścia lat nad tobą mieszkam. Przecież wyście z moim nieżyjącym nieboszczykiem mężem i w Berlinie, i w Kabulu razem strzelali, 
pili, palili, zarażali wroga chorobami wenerycznymi. A twoja nieżyjąca nieboszczka też była dla mnie jak rodzona. Ale trzysta dolarów za zniesienie... (kręci głową)

GENERAE

Akulino Iwanowna, czy pozwolisz, że zadam ci trzy pytania?

\section{BABUSZKA}

Pytaj, synku, pytaj.

\section{BABUSZKA}

Oj, znasz, znasz. To on, ten odchyleniec, ją wczoraj po nocy użył, udusił, zjadł jej lewą rękę, i napoczął nogę. Inna rzecz, że za komunizmu było więcej jedzenia. Teraz to ludzie głodni chodzą.

\section{GENERAŁ}

Ja bym i teraz nogę i rękę dał sobie za Rosję żywcem obciąć, żeby to co pomogło. Ale co ja mogę? Żona nieboszczka zmarła, a ty, Akulino Iwanowna, kapci żeś znowu nie włożyła. Błota naniosłaś.

(Glowacki 1999: 382)

W tym dialogu Generał względem Babuszki używa imienia odojcowskiego. Użycie patronimikum świadczy o obecności dystansu osobistego lub społecznego. W tekście Generał łączy formę adresatywną Akulina Iwanowna z czasownikami w II os. przyszłaś, pozwolisz i pronominalną formą adresatywną ty. Formy te świadczą o przejściu od dystansu społecznego, obecnego na samym początku znajomości, do dystansu osobistego. Odbiorca Babuszka akceptuje zachowywany dystans osobisty, używając familiarnej formy adresatywnej synku i formy zaimkowej ty. Przypuszczamy, że Generał jest osobą o średnim, przejściowym stopniu otwartości na doświadczenie.

PRZYKLAD: 6

EMERYT/GOSPODARZ/TURYSTA/

\section{GOSPODARZ}

Nie pukać, otwarte.

\section{EMERYT}

Zawsze pukam, szanowny panie, otwarte czy zamknięte. Nie do drzwi się bowiem puka, lecz na tamtą stronę. A tam nigdy nie wiadomo, co nas czeka. Kłaniam się szanownym państwu. 


\section{TURYSTKA II}

Proszę pokazać, jakie pan ma. Tak lubię książki.

\section{EMERYT}

Z przyjemnością, szanowna pani.

\section{TURYSTA}

Wszystkie te pan przeczytał?

\section{EMERYT}

O, nie raz, nie raz, szanowny panie. Ale dopiero, gdy zacząłem jeździć.

\section{TURYSTKA I}

Uprawia pan turystykę, tak? A co pan zwiedza, jeśli wolno zapytać?

\section{EMERYT}

W takim znaczeniu, jak szanowna pani pyta, to nic nie zwiedzam. Trudno bowiem zwiedzać z głową w książce.

Emeryt używa tytularnej formy szanowny panie, szanowna pani. Między Emerytem a pozostałymi uczestnikami komunikacji utrzymuje się dystans społeczny. Z kontekstu wynika, że Emeryt jest osobą oczytaną, mądrą, lecz nie ma przesłanek, świadczących o chęci zmiany dystansu. Z tekstu dowiadujemy się, iż Emeryt marzył o podróżowaniu i przez całe życie czekał na emeryturę, po to, by to marzenie spełnić. Emeryt nie podjął próby ani podróżowania w trakcie pracy, ani zmiany pracy na dającą możliwość częstych podróży i czytania książek. Wnioskujemy, że Emeryt jest jednostką ludzką o niskim stopniu otwartości na doświadczenie

\section{PRZYKLAD: 7}

\section{GOSPODARZ}

W wojsku byłem, to nie takieśmy mieli. Każda ścieżka, każdy strumyk, zagajnik...

\section{EMERYT}

Bo to mapa indywidualna, szanowny panie. Poza tym cywilna nie wojskowa. TURYSTA (pałaszując jedzenie, nagle stupieje)

Czekaj no pan. Coś mi to przypomina. (przyklęka nad mapą) Pokazywali kiedyś w telewizji wszechświat 
W podanym fragmencie próbę zmniejszania dystansu względem Emeryta podejmuje Turysta, używając zwrotu czekaj no pan. Formę adresatywną pan odnosimy do form tytularnych, funkcjonujących w dystansie społecznym. Natomiast użycie zwrotu czekaj no traktujemy jako chęć zmiany dystansu na osobisty. Na tę próbę odbiorca w żaden sposób nie zareagował, dlatego proces zmniejszania dystansu nie powiódł się.

\section{PRZYKLAD: 8}

\section{BUSINESSMAN/SMARKULA/EMERYT}

\section{SMARKULA}

Ja bym zjadła kaszanki, Kiziu. Tak dawno nie jadłam kaszanki.

\section{BUSINESSMAN}

Nie kompromituj mnie, Smarkula.

\section{BUSINESSMAN}

Będziesz grzeczna, to będziesz. A na razie nic nie mów. (i do Gospodarza) To jak?

Już w tym miejscu warto podkreślić, iż użycie poufałej formy adresatywnej Kiziu świadczy o dystansie intymnym, który zostaje potwierdzony przez odbiorcę komunikatu.

\section{EMERYT}

Pan szanowny depcze po mojej mapie.

\section{BUSINESSMAN}

Po jakiej mapie? Te esy-floresy to mapa? Drwisz pan ze mnie? Ze mnie? (z wściekłością depcze mapę) Mnie jeszcze nikt!...

\section{DAREK}

A co ja na posługi?

\section{BUSINESSMAN}

Na ochroniarza cię przyjąłem. Nie zrozumiałeś?

\section{DAREK}

Aaa... Znaczy, w mordę, żebym bił?

\section{BUSINESSMAN}


Co tak zaraz ordynarnie?

\section{BUSINESSMAN}

Tylko w razie potrzeby. Tylko $\mathrm{w}$ razie potrzeby. Z zasady przedkładam perswazję nad rękoczyny. Muszę dbać o renomę.

\section{EMERYT}

No, że spowoduje pan wypadek. Nie daj Boże, jeszcze kogoś zabije.

\section{BUSINESSMAN}

Na pewno nie będzie moja wina. (i do Darka) No, czego stoisz?

\section{GOSPODARZ}

Nigdzie nie pójdzie. Nie kazała, to nie kazała.

\section{BUSINESSMAN}

Ech, ty. Dawaj te kluczyki. Zwalniam cię.

(Myśliwski 2012: 710-713)

Z podanego fragmentu tekstu wynika, że Businessman wyraża chęć zmiany dystansu względem odbiorców komunikatu. Businessman zmniejszył dystans interpersonalny, używając pronominalnej formy adresatywnej ty, podczas oferowania pracy Darkowi. W stosunku do Emeryta Businessman w dalszym ciągu używał formy pan, lecz w każdej chwili był gotów przejść na formy obowiązujące w dystansie osobistym, o czym świadczy użycie formy czasownikowej w 2 osobie - drwisz. Bussinesmana można uznać za jednostkę ludzką o wysokim stopniu otwartości na doświadczenia. W tekście niejednokrotnie wspomniany bohater opowiadał, jak z łatwością pokonywał przeszkody pojawiające się na jego drodze życiowej.

\section{PRZYKLAD: 9}

\section{JURIJ/WIERA/POLICJANT}

\section{JURIJ}

Wieroczka, kochanie moje. Ty wiesz, jak mi jest ciężko żyć. Ty jesteś dla mnie jedyną radością.

Wiera, przekonana, ciężko wzdychając, zabiera się do pracy. Wchodzi Policjant.

\section{POLICJANT}

Obywatelko, przerwać rozkosz. Dokumenty.

Jurij macha ręka, żeby się odczepił. 
Policjant wyciaga pałkę. Jurij wściekły podnosi się w całej okazałości, zrywa policjantowi epolety $i$ wali go $w$ twarz.

POLICJANT (rozpoznajac go)

Przepraszam, Juriju Aleksiejewiczu. Nie poznałem. Proszę, wybaczcie. (zbiera epolety) Proszę sobie nie przeszkadzać. (mruga porozumiewawczo) Jakby coś, to ja tu jestem w pobliżu.

Jurij niechętnie daje znak ręka, żeby spływat. W tym momencie dzwoni mu w spodniach telefon komórkowy.

JURIJ (do telefonu)

Tak, tak, kochanie. Zaraz będę. (zapinając spodnie) Żyć nie dają. (do Wiery) Pa, kochanie, do jutra.

(Glowacki 1999: 407)

Zachowanie Jurija względem Policjanta można uznać za aroganckie, natomiast łatwość, z jaką tego dokonuje, może świadczyć o wysokim stopniu otwartości na doświadczenie. Jurij jest osobą odnoszącą sukcesy. Cieszy się poszanowaniem w środowisku legislacyjnym. Stawia przed sobą cele i je realizuje. W tekście używa form ty, cię, poufałej formy adresatywnej kochanie, zdrobniałej formy Wieroczka. Względem Wieroczki zachowuje dystans intymny, dowodem czego są użyte formy adresatywne.

\section{PRZYKLAD: 10}

\section{JURIJ/WIERA/GENERAŁ}

JURIJ

Dobry wieczór, Wieroczka. (wręcza jej kwiaty) Ostatnio poprztykaliśmy się trochę, jak to zakochani. Ale przecież to nic poważnego. Kochamy się, a miłość jest w życiu najważniejsza. (wyciaga z kieszeni flaszke whisky) Johnnie Walker Black. (siada obok Generała. Na łóżku napetnia szklanki, trąca się z Generałem)

Wypijaja.

JURIJ (do Generała)

Zaganiany jestem, Iwanie Piotrowiczu, bo to z jednej strony rozwód, (zerka na Wierę, która siedzi z kwiatami i wytrzeszczonymi oczami) z drugiej polityka. A pieniędzy ciągle mało.

Napetnia szklanki. Wypijaja.

\section{GENERAL}

Juriju Aleksiejewiczu, czy jest nadzieja, że będzie wojna? (Głowacki 1999: 483) 
W podanym fragmencie tekstu Jurij w dalszym ciągu zachowuje względem Wieroczki dystans intymny. Do jej ojca Generała zwraca się za pośrednictwem patronimikum. Generał odpowiada, również używając imienia odojcowskiego. Wspólne wypicie alkoholu świadczy o obecności procesu zmniejszania dystansu. Jurija możemy uznać za osobę o wysokim stopniu otwartości na doświadczenia.

\section{Wnioski}

Analiza tekstów literackich Wiesława Myśliwskiego Requiem dla gospodyni i Janusza Głowackiego Czwarta siostra $\mathrm{z}$ zastosowaniem koncepcji dystansów interpersonalnych pozwoliła uzyskać ciekawe wyniki. Na przykładzie analizowanych bohaterów dramatu odkryliśmy zależność między chęcią zmniejszania dystansu interpersonalnego a stopniem otwartości na doświadczenie. Emeryt jest osobą o niskim stopniu otwartości na doświadczenia. Świadczy o tym użycie przez niego wyłącznie form adresatywnych należących do dystansu społecznego. Darek, Gospodarz, Generał, są osobami o pośrednim stopniu otwartości na doświadczenia, używają różnych form adresatywnych, lecz nie wykazują dużych chęci zmiany dystansu interpersonalnego. Businessman i Jurij Aleksiejewicz są osobami o wysokim stopniu otwartości na doświadczenie, bezproblemowo zmniejszającymi dystans interpersonalny obecny między nadawcą a odbiorcą komunikatu.

Praca $\mathrm{z}$ tekstem nie pozwala $\mathrm{w}$ pełni przeanalizować chęci zmniejszania dystansów interpersonalnych $\mathrm{w}$ różnych dziedzinach naszego życia. Dlatego widzimy potrzebę zweryfikowania tej koncepcji na jednostkach ludzkich. Z przykładami zmniejszania dystansu możemy spotkać się na ulicy, jadąc w tramwaju, będąc szkole wyższej itp. Przeprowadzenie z ludźmi krótkich wywiadów pozwoli zaobserwować, jakich form używają przy pierwszym spotkaniu i w jaki sposób formy te zmieniają się w procesie dalszej komunikacji. Dobór grupy docelowej możemy oprzeć na zawodach, wykonywanych przez osoby badane. Wydaje nam się, że poziom, którego nie był w stanie zmierzyć Rogers, ani jego następcy jest ściśle związany z dystansem, zawsze obecnym przy zwracaniu się i kontynuacji komunikacji międzyludzkiej.

\section{Bibliografia}


Austin, Langshaw ([1962] 1993) Mówienie i poznawanie: rozprawy i wykłady filozoficzne: Jak działać stowami. [How to do things with words. London: Oxford Uniwersity Press] (tłum.) J. Woleński. Warszawa: Wydawnictwo Naukowe PWN.

Cialdini, Robert ([2008] 2013) Wywieranie wptywu na ludzi. [Influence. Science and Practice. Boston: Allyn \& Bacon] (tłum.) B. Wojciszke. Gdańsk: Gdańskie Wydawnictwo Pedagogiczne.

Ciszewska-Mlinarič, Mariola, Aleksandra Wąsowska (2012) „Znaczenie dystansu w procesie internacjonalizacji przedsiębiorstw" Management and Business Administration. Central Europe, Vol. 20 (No. 6); 3-22.

Erikson, H. Erik ([1963] 1997) Dzieciństwo i społeczeństwo. [Childhood and Society. Nowy Jork: W. W. Norton \& Company] (tłum.) P. Hejmej. Poznań: Dom Wydawniczy Rebis.

Głowacki, Janusz ([1999]/2012) „Czwarta siostra”. [W:] Trans/formacja. Dramat polski po 1989 roku. Antologia: tom I. (red.) J. Kopciński, G. Wroniewicz. Warszawa: Instytut Badań Literackich PAN. 377-486

Hall, Edward ([1966] 1978) Ukryty wymiar. [The Hidden Demension. Santa Fe: Edward T. Hall] (tłum.) T. Hołówka. Warszawa: Państwowy Instytut Wydawniczy.

Johanson, Jan, Jan-Erik Vahlne (1977) „The internationalization process of the firm - a model of knowledge development and increasing foreign market commitments" Journal of International Business Studies, Vol. 8 (No. 1); 23-32.

Pervin, A. Lawrens, John P. Oliver ([2001] 2002) Osobowość - teorie i badania. [Personality: theory and research. Hoboken: John Wiley \& Sons, Inc.] (tłum.) K. Krzyżewski. Kraków: Wydawnictwo Uniwersytetu Jagiellońskiego.

Myśliwski, Wiesław ([2000]/2012) „Requiem dla gospodyni”. [W:] Trans/formacja. Dramat polski po 1989 roku. Antologia: Tom I. (red.) J. Kopciński, G. Wroniewicz. Warszawa: Instytut Badań Literackich PAN. 627-730.

Rogers, R. Carl ([1961] 2002) O stawaniu się osoba. [On becoming a Person. Boston: Houghton Mifelin Company] (tłum.) M. Karpiński. Poznań: Dom Wydawniczy Rebis.

Rogers, R. Carl ([1980] 2012) Sposób bycia. [A Way of Being. Boston: Houghton Mifelin Company](tłum.) M. Karpiński. Poznań: Dom Wydawniczy Rebis.

Rogers, R. Carl ([1959] 2016) Teoria terapii, osobowości i relacji interpersonalnych, rozwinięta w oparciu o podejście skoncentrowane na kliencie. [A theory of therapy, personality, and interpersonal relationships, as developed in the client-centered framework. Nowy Jork: McGraw-Hill Book Company] (tłum.) M. Król. Warszawa: Wydawnictwo Zielone Drzewo Instytut Psychologii Zdrowia PTP. 
Tomiczek, Edward (1983) System adresatywny wspótczesnego języka polskiego i niemieckiego. Socjolingwistyczne studium konfrontatywne, Wrocław: Wydawnictwo Uniwersytetu Wrocławskiego. 